\title{
Ants (Hymenoptera: Formicidae) from an Amazonian fragmented landscape, Juara, Mato Grosso, Brazil, with new records of ant species
}

\author{
Ricardo Eduardo Vicente ${ }^{1,2,6}$, Alexandre Casadei Ferreira ${ }^{3}$, Rogério Conceição Lima dos Santos ${ }^{4}$ \& Lívia Pires do Prado ${ }^{5}$ \\ 1 Universidade do Estado de Mato Grosso (UNEMAT), Centro de Tecnologia na Amazônia (CETAM), \\ Laboratório de Biologia Vegetal. Alta Floresta, MT, Brasil. \\ 2 Universidade Federal de Mato Grosso (UFMT), Instituto de Biociências (IB), Centro de Biodiversidade, \\ Laboratório de Ecologia de Comunidades. Cuiabá, MT, Brasil. \\ 3 Universidade Federal do Paraná (UFPR), Departamento de Zoologia (DZO0), Laboratório de Sistemática e Biologia de Formigas (LSBF). \\ Curitiba, PR, Brasil. ORCID: 0000-0002-2977-8348. E-mail: alexandrefrreira@gmail.com \\ ${ }^{4}$ Universidade Federal de Mato Grosso (UFMT), Instituto de Biociências (IB), Centro de Biodiversidade, Programa de Pós-Graduação em Ecologia \\ e Conservação da Biodiversidade (PPG-ECB). Cuiabá, MT, Brasil. ORCID: 0000-0002-5772-8188. E-mail: roger.c.l.santos@gmail.com \\ ${ }^{5}$ Museu Paraense "Emílio Goeldi" (MPEG), Coordenação de Ciências da Terra e Ecologia (CCTE), Programa de Pós-Graduação em Zoologia \\ (PPGZ00L), Laboratório de Morfologia e Ecologia Funcional de Formigas. Belém, PA, Brasil. ORCID: 0000-0003-1819-8767. \\ E-mail: livia.pires7@gmail.com \\ ${ }^{6}$ ORCID: 0000-0003-2640-2537.E-mail: ricardomyrmex@gmail.com
}

\begin{abstract}
The state of Mato Grosso is the $3^{\text {rd }}$ largest Brazilian state, is covered with three major Brazilian biomes, including the Pantanal, Cerrado, and Amazonia. To date, 449 ant species are recorded in literature for the state. In the present work, we documented the ants sampled along a fragmented landscape, in the municipality of Juara, in the Cerrado-Amazon transition zone in the state of Mato Grosso, Brazil. The ant species were captured with Pitfall traps installed in 20 trails with 10 traps in each (totaling 200). Our results show 151 species, belonging to 43 genera and eight subfamilies, of which 28 species were recorded for the first time in the state and five species recorded for the first time in Brazil. Most genera collected were Pheidole Westwood, 1839 (45 species) followed by (rematogaster Lund, 1831 (11 species). By highlighting species recorded for the first time in state of Mato Grosso and Brazil, we hope to encourage new discoveries and increase the general knowledge of the ant fauna of different biomes in the region.
\end{abstract}

Key-Words. Distibution; Neotropical fauna; Pitfall trap; Sampling method; Species inventories.

\section{INTRODUCTION}

The state of Mato Grosso is the $3^{\text {rd }}$ largest Brazilian state (IBGE, 2017) and as well as the Amazon and Cerrado, there is still the Pantanal in its political-geographic limits (Silva et al., 2013; Mateus et al., 2016; Vicente et al., 2016). In the region of Meridional Amazon present in the north of the state of Mato Grosso, there is a great extension of Forest of transition between Amazonia and Cerrado (Paolucci et al., 2016; Vicente et al., 2016). The biodiversity of southern Amazonia is sparsely known (Santos-Silva et al., 2016; Vicente et al., 2016) especially in these transition areas (Paolucci et al., 2016; Vicente et al., 2016).

In relation to regional ant fauna, 449 species were recorded for the Mato Grosso state, belonging to 78 genera and nine subfamilies (Janicki et al., 2016). In recent years the number of inven- tories published in the region has increased (e.g., Battirola et al., 2005; Rocha et al., 2015; Vicente et al., 2016). This scenario has been reversed due to Formicidae characteristics such as ease of sampling because of its high abundance, species richness and relatively well-known taxonomy, biology and ecology, added to the role of biodiversity in ecosystem functioning making ants an attractive group to evaluate and monitor environmental attributes (Agosti et al., 2000; Ribas et al., 2012). In addition, online tools are available for species identification and distribution (e.g., Antweb.org, AntMaps.org [Janicki et al., 2016], AntWiki and others) increasing the number of taxonomists and consolidating working groups.

Considering that strategies for the conservation and knowledge of Brazilian biodiversity are based mainly in species richness, the role of species lists is central for knowledge of the ant fauna 
(Ulysséa et al., 2011; Suguituru et al., 2013). For this reason, and due to the vegetation formations of the region, this work aimed to describe the richness and composition of the ant fauna between an Amazon-Cerrado ecotone landscape in the city of Juara, MT, Brazil. We intend to present a list of the ant species of the region with new records for the state of Mato Grosso and to Brazil.

\section{MATERIAL AND METHODS}

\section{Study area}

Samples were carried out on four fragments in a whole fragmented Amazon landscape immersed in a pasture matrix on the banks of the Arinos river, municipality of Juara, north of Mato Grosso state, Brazil $\left(09^{\circ} 28^{\prime} \mathrm{S}\right.$, $55^{\circ} 50^{\prime} \mathrm{W}$ ). Juara has an area of $22,622 \mathrm{~km}^{2}$ with $34.87 \%$ of its original area deforested (INPE, 2015; IBGE, 2017). The vegetation of the region is characterized by the transition of Cerrado-Amazon areas (Ávila \& Kawashita-Ribeiro, 2011) and by secondary forests, with the presence of rocky outcrops and agricultural activities. The sampling protocol used in this study is the RAPELD methodology (Costa \& Magnusson, 2010). Each Module has sets of five trails of $250 \mathrm{~m}$ in length at a minimum distance of $1 \mathrm{~km}$ from each other, totaling twenty trails (Fig. 1). Module 4 is the nearest to the urban center, about $8.5 \mathrm{~km}$ in distance, and Module 2 and 3, the farthest, at about $29.5 \mathrm{~km}$.

\section{Data sampling}

The ant inventory was conducted in February 2015 in four areas (denominated here as a module). In each module we collected in five trails, with a distance of 1,000 meters between them (Fig. 1), totalizing 20 sample units. Of these 20 trails, four were planted on the islands of the Rio Arinos. In each trail, we used two sampling methods, the first consisting of ten solo pitfall traps, distributed with a distance of $15 \mathrm{~m}$ between them. The traps remained for 72 consecutive hours in each sampling area.

In addition to pitfall traps, we use a second method, attractive baits of sardine and honey. The baits placed on $20 \mathrm{~cm} \times 10 \mathrm{~cm}$ paper napkin 10 meters distance from each other in an intercalated manner on the ground and vegetation. We randomized the first stratum to be sampled. We put about $5 \mathrm{~g}$ of sardines on the ground and in understory trees we put a teaspoon of bee's honey. Therefore, we had 20 sub-sample baits in each trail that remained exposed for approximately one hour. Unfortunately, the information on the type of bait and the stratum in which it was placed was not recovered.

\section{Ant identification}

To identify subfamilies and genera of sampled ants we used the dichotomous key available in Baccaro et al. (2015). Thereafter, we used several taxonomic keys

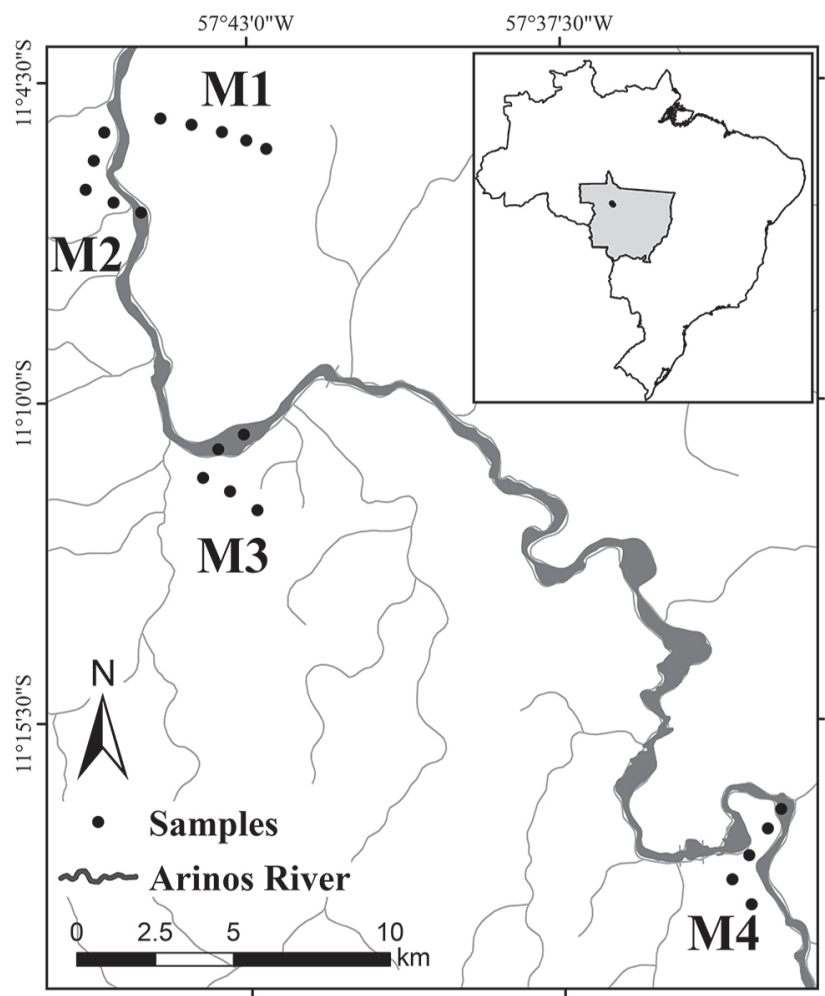

Figure 1. Map indicating the Modules $(M)$ where the samples were collected in the municipality of Juara, north of Mato Grosso state, Brazil. The four points on the Arinos River represent samples taken on islands.

(Brandão, 1990; Fernández, 2003; Longino, 2003; Wilson, 2003; Mackay \& Mackay, 2010; Fernandes et al., 2014) to identify to a specific level or to separate into morphospecies. We also made comparisons with specimens deposited at the Entomological collections of the Museu Paraense Emílio Goeldi (MPEG) and Padre Jesus Santiago Moure of the Departamento de Zoologia da Universidade Federal do Paraná (DZUP) and consulted specialists to confirm species identification (see Acknowledgements).

\section{Repositories}

The ant vouchers were deposited at the Laboratório de Ecologia de Comunidades of the Centro de Biodiversidade da Universidade Federal de Mato Grosso (UFMT), Entomological Collection of the Museu Paraense Emílio Goeldi (MPEG) and Coleção Entomológica Padre Jesus Santiago Moure of the Departamento de Zoologia da Universidade Federal do Paraná (DZUP).

\section{RESULTS}

We recorded a total of 151 species and morphospecies of ants belonging to 43 genera and eight subfamilies (Table 1). The most specious genus was Pheidole with 45 species (30\% of Mirmicinae), of which 27 species are unidentified. Other representative genera regarding the number of species were Crematogaster with 11 species and posteriorly Camponotus, Gnamptogenys, and 
Table 1. List of ant species recorded at an Amazonian fragmented landscape, municipality of Juara, Mato Grosso state, Brazil. Twenty four ants species were sampled for the first time in Mato Grosso state* and four ant species sampled for the first time in Brazil**.

\begin{tabular}{|c|c|c|c|}
\hline Subfamily/Species & Number of taxa and method of sample & Subfamily/Species & Number of taxa and method of sample \\
\hline DORYLINAE & 1 genus and 2 species & Apterostigma & 3 species \\
\hline Eciton & 2 species & Apterostigma megacephala Lattke, 1999 & Pitfall \\
\hline Eciton burchellii (Westwood, 1842) & Pitfall & Apterostigma urichii Forel, 1893 & Pitfall \\
\hline Eciton aff. burchellii & Pitfall & Apterostigma sp.2 & Pitfall and bait \\
\hline DOLICHODERINAE & 4 genera and 8 species & Atta & 2 species \\
\hline Dolichoderus & 4 species & Atta sexdens (Linnaeus, 1758) & Pitfall \\
\hline Dolichoderus attelaboides (Fabricius, 1775) & Pitfall and bait & Atta aff. bisphaerica & Pitfall and bait \\
\hline Dolichoderus bidens (Linnaeus, 1758) & Pitfall & Blepharidatta & 1 species \\
\hline Dolichoderus bispinosus (0livier, 1792) & Pitfall & Blepharidatta brasiliensis Wheeler, 1915 & Pitfall and bait \\
\hline Dolichoderus imitator Emery, 1894 & Pitfall & Cardiocondyla & 1 species \\
\hline Dorymyrmex & 1 species & Cardiocondyla obscurior Wheeler, 1929 & Pitfall \\
\hline Dorymyrmex insanus (Buckley, 1866) & Pitfall and bait & Carebara & 1 species \\
\hline Linepithema & 2 species & Carebara brevipilosa Fernández, 2004 & Pitfall \\
\hline Linepithema cerradense Wild, 2007* & Pitfall and bait & Cephalotes & 1 species \\
\hline Linepithema neotropicum Wild, 2007 & Bait & Cephalotes atratus (Linnaeus, 1758) & Pitfall and bait \\
\hline Tapinoma & 1 species & Crematogaster & 11 species \\
\hline Tapinoma ramulorum Emery, 1896 & Bait & Crematogaster brasiliensis Mayr, 1878 & Pitfall and bait \\
\hline ECTATOMMINAE & 2 genera and 12 species & Crematogaster carinata Mayr, 1862 & Pitfall and bait \\
\hline Ectatomma & 4 species & Crematogaster erecta Mayr, 1866 & Pitfall and bait \\
\hline Ectatomma brunneum Smith, 1858 & Pitfall & Crematogaster evallans Forel, 1907* & Pitfall \\
\hline Ectatomma lugens Emery, 1894 & Pitfall & Crematogaster flavosensitiva Longino, 2003* & Pitfall \\
\hline Ectatomma muticum Mayr, $1870^{*}$ & Pitfall and bait & Crematogaster levior Longino, 2003 & Pitfall and bait \\
\hline Ectatomma tuberculatum (Olivier, 1792) & Pitfall and bait & Crematogaster limata Smith, 1858 & Pitfall and bait \\
\hline Gnamptogenys & 8 species & Crematogaster nigropilosa Mayr, 1870 & Pitfall and bait \\
\hline Gnamptogenys acuminata (Emery, 1896) & Pitfall & Crematogaster sotobosque Longino, 2003* & Bait \\
\hline Gnamptogenys concinna (Smith, 1858) & Pitfall & Crematogaster tenuicula Forel, 1904 & Pitfall and bait \\
\hline Gnamptogenys horni (Santschi, 1929) & Pitfall & Crematogaster sp.1 & Pitfall \\
\hline Gnamptogenys mina (Brown, 1956)* & Pitfall & Cyphomyrmex & 4 species \\
\hline Gnamptogenys moelleri (Forel, 1912) & Pitfall and bait & Cyphomyrmex laevigatus Weber, 1938 & Pitfall and bait \\
\hline Gnamptogenys relicta (Mann, 1916) & Pitfall & Cyphomyrmex vorticis Weber, $1940^{*}$ & Pitfall \\
\hline Gnamptogenys vriesi Brandão \& Lattke, 1990 & Pitfall & Cyphomyrmex aff. minutus & Pitfall \\
\hline Gnamptogenys aff. lanei & Pitfall & Cyphomyrmex aff. rimosus & Pitfall \\
\hline FORMICINAE & 4 genera and 19 species & Megalomyrmex & 1 species \\
\hline Brachymyrmex & 2 species & Megalomyrmex sp.1 & Pitfall and bait \\
\hline Brachymyrmex sp.1 & Pitfall and bait & Mycetophylax & 1 species \\
\hline Brachymyrmex sp.2 & Bait & Mycetophylax sp.1 & Pitfall and bait \\
\hline Camponotus & 8 species & Mycocepurus & 1 species \\
\hline Camponotus atriceps (Smith, 1858) & Pitfall & Mycocepurus smithii (Forel, 1893) & Pitfall \\
\hline Camponotus femoratus (Fabricius, 1804) & Pitfall and bait & Nesomyrmex & 1 species \\
\hline Camponotus leydigi Forel, 1886 & Pitfall and bait & Nesomyrmex sp.1 & Pitfall \\
\hline Camponotus novogranadensis Mayr, 1870 & Pitfall and bait & Ochetomyrmex & 1 species \\
\hline Camponotus planatus Roger, 1863 & Pitfall and bait & Ochetomyrmex neopolitus Fernández, 2003 & Pitfall and bait \\
\hline Camponotus substitutus Emery, 1894 & Pitfall and bait & Octostruma & 1 species \\
\hline Camponotus sp.1 & Pitfall & Octostruma balzani (Emery, 1894) & Pitfall \\
\hline Camponotus sp.2 & Pitfall & Pheidole & 45 species \\
\hline Gigantiops & 1 species & Pheidole biconstricta Mayr, 1870 & Pitfall and bait \\
\hline Gigantiops destructor (Fabricius, 1804) & Pitfall & Pheidole bufo Wilson, 2003 & Pitfall and bait \\
\hline Nylanderia & 8 species & Pheidole cataractae Wheeler, $1916^{*}$ & Pitfall and bait \\
\hline Nylanderia fulva (Mayr, 1862) & Pitfall and bait & Pheidole coffeicola Borgmeier, 1934* & Pitfall \\
\hline Nylanderia steinheili (Forel, 1893) & Pitfall and bait & Pheidole deima Wilson, 2003* & Pitfall \\
\hline Nylanderia aff. caeciliae & Pitfall & Pheidole germaini Emery, 1896 & Bait \\
\hline Nylanderia sp.1 & Bait & Pheidole leonina Wilson, 2003* & Pitfall \\
\hline Nylanderia sp.2 & Pitfall and bait & Pheidole lovejoyi Wilson, 2003* & Pitfall \\
\hline Nylanderia sp.3 & Pitfall & Pheidole microps Wilson, 2003** & Pitfall \\
\hline Nylanderia sp.6 & Pitfall & Pheidole oxyops Forel, 1908 & Pitfall \\
\hline Nylanderia sp.7 & Pitfall and bait & Pheidole paraensis Wilson, 2003* & Pitfall \\
\hline MYRMICINAE & 21 genera and 90 species & Pheidole scolioceps Wilson, 2003* & Bait \\
\hline Acromyrmex & 1 species & Pheidole sculptior Forel, 1893** & Bait \\
\hline Acromyrmex sp.1 & Pitfall & Pheidole sensitiva Borgmeier, 1959* & Pitfall and bait \\
\hline
\end{tabular}




\begin{tabular}{|c|c|}
\hline Subfamily/Species & Number of taxa and method of sample \\
\hline Pheidole strigosa Wilson, 2003* & Pitfall \\
\hline Pheidole triconstricta Forel, 1886 & Pitfall and bait \\
\hline Pheidole vallifica Forel, 1901* & Pitfall \\
\hline Pheidole vorax (Fabricius, 1804) & Pitfall \\
\hline Pheidole sp.1 & Pitfall and bait \\
\hline Pheidolesp.2 & Pitfall \\
\hline Pheidolesp.3 & Pitfall \\
\hline Pheidolesp.4 & Pitfall and bait \\
\hline Pheidole sp.5 & Bait \\
\hline Pheidolesp.6 & Pitfall \\
\hline Pheidole sp.7 & Pitfall \\
\hline Pheidole sp.8 & Bait \\
\hline Pheidolesp.9 & Pitfall \\
\hline Pheidole sp.10 & Pitfall \\
\hline Pheidole sp.11 & Pitfall \\
\hline Pheidolesp.12 & Pitfall \\
\hline Pheidole sp.13 & Pitfall \\
\hline Pheidole sp.14 & Pitfall \\
\hline Pheidole sp.15 & Pitfall \\
\hline Pheidole sp.16 & Pitfall \\
\hline Pheidole sp.17 & Pitfall \\
\hline Pheidole sp.18 & Pitfall \\
\hline Pheidole sp.19 & Pitfall \\
\hline Pheidole sp.20 & Pitfall \\
\hline Pheidole sp.21 & Pitfall \\
\hline Pheidole sp.22 & Pitfall \\
\hline Pheidole sp.23 & Bait \\
\hline Pheidole sp.24 & Pitfall \\
\hline Pheidole sp.25 & Pitfall \\
\hline Pheidole sp.26 & Pitfall \\
\hline Pheidole sp.27 & Bait \\
\hline Sericomyrmex & 2 species \\
\hline Sericomyrmex saussurei Emery, 1894 & Pitfall and bait \\
\hline Sericomyrmex sp.3 & Pitfall and bait \\
\hline Solenopsis & 5 species \\
\hline Solenopsis invicta Buren, 1972 & Pitfall and bait \\
\hline Solenopsis sp.1 & Pitfall and bait \\
\hline Solenopsis sp.2 & Pitfall \\
\hline Solenopsis sp.4 & Pitfall and bait \\
\hline Solenopsis sp.7 & Pitfall \\
\hline Strumigenys & 2 species \\
\hline Strumigenys denticulata Mayr, 1887 & Pitfall \\
\hline
\end{tabular}

Nylanderia with eight species each. In contrast, $51 \%$ of the genera sampled were represented by only one species.

Of these 151 sampled ant species, 23 species were collected for the first time in Mato Grosso state. Of these 23 species, three species were sampled for the first time in Brazil (Table 1). The subfamily with the largest number of species sampled for the first time in the locality was Myrmicinae, with 17 new records, 12 of which were only of the Pheidole genus. In relation to sampling methods, of these 151 ant species, 83 species were sampled exclusively in pitfall (55\%), twelve species using baits (8\%) and 56 with both methods (37\%). As regards the 28 species that are new records, 16 species were sampled exclusively with pitfall and four only in baits and eight ant species in both methods.

\begin{tabular}{|c|c|}
\hline Subfamily/Species & Number of taxa and method of sample \\
\hline $\begin{array}{l}\text { Strumigenys zeteki (Brown, 1959)* } \\
\text { (1) }\end{array}$ & Pitfall \\
\hline Trachymyrmex & 4 species \\
\hline Trachymyrmex sp.1 & Pitfall and bait \\
\hline Trachymyrmex sp.3 & Pitfall \\
\hline Trachymyrmex sp.4 & Pitfall \\
\hline Trachymyrmex sp.5 & Pitfall \\
\hline Wasmannia & 1 species \\
\hline Wasmannia auropunctata (Roger, 1863) & Pitfall and bait \\
\hline PARAPONERINAE & 1 genus and 1 species \\
\hline Paraponera & 1 species \\
\hline Paraponera clavata (Fabricius, 1775) & Pitfall and bait \\
\hline PONERINAE & 9 genera and 16 species \\
\hline Anochetus & 1 species \\
\hline Anochetus targionii Emery, 1894 & Pitfall \\
\hline Dinoponera & 1 species \\
\hline Dinoponera mutica Emery, 1901 & Pitfall \\
\hline Hypoponera & 1 species \\
\hline Hypoponera sp.3 & Pitfall \\
\hline Leptogenys & 1 species \\
\hline Leptogenys aff. gaigei & Pitfall \\
\hline Mayaponera & 1 species \\
\hline Mayaponera constricta (Mayr, 1884) & Pitfall and bait \\
\hline Neoponera & 5 species \\
\hline Neoponera apicalis (Latreille, 1802) & Pitfall and bait \\
\hline Neoponera magnifica (Borgmeier, 1929)* & Pitfall \\
\hline Neoponera verenae Forel, 1922 & Pitfall \\
\hline Neoponera villosa (Fabricius, 1804) & Pitfall and bait \\
\hline Neoponera commutata (Roger, 1860) & Pitfall and bait \\
\hline Odontomachus & 3 species \\
\hline Odontomachus chelifer (Latreille, 1802) & Pitfall \\
\hline Odontomachus haematodus (Linnaeus, 1758) & Pitfall and bait \\
\hline Odontomachus meinerti Forel, 1905 & Pitfall \\
\hline Pachycondyla & 2 species \\
\hline Pachycondyla crassinoda (Latreille, 1802) & Pitfall and bait \\
\hline Pachycondyla harpax (Fabricius, 1804) & Pitfall and bait \\
\hline Simopelta & 1 species \\
\hline Simopelta jeckylli (Mann, 1916) & Pitfall \\
\hline PSEUDOMYRMEX & 1 genera and 3 species \\
\hline Pseudomyrmex & 3 species \\
\hline Pseudomyrmex gracilis (Fabricius, 1804) & Pitfall and bait \\
\hline Pseudomyrmex peruvianus (Wheeler, 1925)** & Pitfall and bait \\
\hline Pseudomyrmex tenuis (Fabricius, 1804) & Pitfall and bait \\
\hline
\end{tabular}

\section{DISCUSSION}

Our results expand the current knowledge about ant species in the state of Mato Grosso, focusing in the region of Juara - in the Cerrado-Amazon transition zone. In the Neotropics, the ecotonal zones are present in many landscapes and can influence in different ways, such as faunal movement, flow of energy and nutrients, population dynamics, species interactions and changes in vegetation structure (Spector \& Ayzama, 2003). In addition, the areas of transition in terrestrial ecosystems can present high species diversity and may be revealing indicators of the consequences of global climate changes (Zhu et al., 2011, Malanson et al., 2017).

Despite the importance of these areas for biodiversity little is known about the ant fauna in these formations 
since 23 species of one inventory in an ecotone area are recorded for the first time in Mato Grosso. This number is very representative considering that it represents $15 \%$ of the sampled ant species. Including these species, three species had not been sampled so far in Brazil, which were Pheidole microps Wilson, 2003, Pheidole sculptior Forel, 1893 and Pseudomyrmex peruvianus (Wheeler, 1925). Among these species that were sampled for the first time in the State of Mato Grosso, 12 species were of the genus Pheidole (41.4\%). This genus represents the second largest among ants, with 1.004 known species (Bolton, 2018) (7\% of all Formicidae diversity) and the largest for the Neotropical region with over 600 species (AntWiki, 2018), which represents more than $14 \%$ of all known species for the same region. No other biogeographical region has such Pheidole species, apart from the Afrotropical and Indo-Autralian regions which have just over 150 species (AntWiki, 2018). Due to this large number of species, it is expected that most of the work involving fauna inventory lacks identifications for this genus. This results in a disjunctive distribution of Pheidole species, mainly in the southern Neotropical and consequently presenting an impressive amount of new records ( 12 only for the present paper). In addition to the richness, Pheidole lacks an efficient method of identification, since the most recent dichotomous key (Wilson, 2003) was designed only for major workers, who are relatively little sampled in passive methods (pitfall and Winkler) and the correct association with the minor workers is extremely difficult.

At the same time, the genus has an interactive key developed on the Lucid platform by Pheidole Working group and was updated by Longino (2009). However, this key is not appropriate for finding an exact identification but is restricted to a list of names that needs to be consulted in the descriptions and images available. The lack of studies involving the Pheidole taxonomy for the New World has been added to these problems, with the most recent and comprehensive publications being those of Wilson (2003) for the New World, Longino (2009) focused on Central America, and a few new species described posteriorly (e.g., Pheidole protaxi Oliveira \& Lacau, 2015 in Oliveira et al., 2015). The necessity of studies focused on Pheidole for these regions has already been pointed out by Longino (2009) and is one of the limits reguarding our knowledge for the genus.

Nevertheless, although not being a new record for Mato Grosso state, some species sampled are rarely collected, with several gaps in the distribution. Dorymyrmex insanus (Buckley, 1866) has records from the northern United States (Wheeler \& Wheeler, 1988) to Paraguay (Brandão, 1991; Fernández \& Sendoya, 2004) with several gaps in the Neotropic. However, its real distribution is unknown, since the last revisions of Dorymyrmex are sectoralized and almost absent with focus on Neotropical species (Johnson, 1989; Snelling, 1995; Cuezzo \& Guerrero, 2011). For this reason, a complete review of the group focusing on tropical species is necessary and can greatly clarify and broaden the distribution of many species.

Of the 151 species sampled, 83 species were sampled exclusively in pitfall $(54.97 \%), 12$ species using baits
(7.95\%) and 56 with both methods (37.09\%). Although bait is an attractive method, pitfall sampled more species. Ryder-Wilkie et al. (2010) also found this pattern comparing several methods of collecting ants in the Peruvian Amazon. This pattern can be explained by some factors. First, the attractive baits remain in the field for one hour and then the attracted ants are collected, while the pitfall, although not attracting, intercepts the ants that are foraging on the ground. In addition, ants are known for their aggressiveness and territoriality (Hölldobler, 1979; Vicente et al., 2014; Dejean et al., 2015), and by colonizing a resource, prevent other ants from accessing it by controlling the diversity of species in the bait while in the pitfall there is no such intervention of dominant species.

In summary, our work lists the ant diversity in a poorly known Meridional Amazon region, contributing to the knowledge of the Amazonia-Cerrado transition biomes. This work extends the distribution of 23 species for Mato Grosso state. Nevertheless, more intensive sampling at diverse locations in the region using different methods of sampling is necessary to get a more comprehensive idea about ant fauna.

\section{ACKNOWLEDGEMENTS}

We thank the researchers Lorhaine Santos-Silva for assistance in the laboratory and Gabriela Camacho [DZUP], Mayron Escárraga [DZUP], Rodrigo Feitosa [DZUP], Thiago Sanches Ranzani da Silva [DZUP], Lina Hernández [IAVH], Emília Z. Albuquerque [MPEG] and Rony Peterson Almeida [MPEG] for their help with the identification/ confirmation of the ant species. REV thanks Fundação de Amparo à Pesquisa do Estado de Mato Grosso, Conselho Nacional de Desenvolvimento Científico e Tecnológico (FAPEMAT/CNPq № 003/2016 - DCR), Museu Paraense Emilio Goeldi and Ministério da Ciência, Tecnologia, Inovações e Comunicações (PCl-MPEG/MCTIC № 301081/2017-4) for your research fellowship. LPP was financed by the Coordenação de Aperfeiçoamento de Pessoal de Nível Superior - Brasil (CAPES) - Finance Code 001 and by Programa de Capacitação Institucional do CNPq (MPEG/MCTI, CNPq/PCI-DC 313168/2016-4). ACF was financed by Conselho Nacional de Desenvolvimento Científico e Tecnológico [CNPq 140260/2016-1]

\section{REFERENCES}

Agosti, D.; Majer, J.D.; Alonso, L.E.; \& Schultz, T.R. (Eds.). 2000. Ants: Standard methods for measuring and monitoring biodiversity. Washington, Smithsonian Institution Press.

AntWiki. 2018. AntiWiki. Available at: www.antwiki.org. Access in: 19/02/2018.

Ávila, R.W. \& Kawashita-Ribeiro, R.A. 2011. Herpetofauna of São João da Barra Hydroelectric Plant, state of Mato Grosso, Brazil. Check List, 7(6): 750-755.

Baccaro, F.B.; Feitosa, R.M.; Fernández, F.; Fernandes, I.0.; Izzo, T.J.; Souza, J.L.P. \& Solar, R.R.C. 2015. Guia para os gêneros de formigas do Brasil. Manaus, Editora INPA. DOI 
Battirola, L.D.; Marques, M.I.; Adis, J. \& Delabie, J.H.C. 2005. Composição da comunidade de Formicidae (Insecta, Hymenoptera) em copas de Attalea phalerata Mart. (Arecaceae), no Pantanal de Poconé, Mato Grosso, Brasil. Revista Brasileira de Entomologia, 49(1): 107-117.

Bolton, B. 2018. An online catalog of the ants of the world. Available at: www. antcat.org. Access in: 19/02/2018.

Brandão, C.R.F. 1990. Systematic revision of the Neotropical ant genus Megalomyrmex Forel (Hymenoptera: Myrmicinae), with the description of thirteen new species. Arquivos de Zoologia, 31: 411-494. D0I

Brandão, C.R.F. 1991. Adendos ao catalogo abreviado das formigas da região neotropical (Hymenoptera: Formicidae). Revista Brasileira de Entomologia, 35: 319-412.

Costa, F.R.C. \& Magnusson, W.E. 2010. The need for large-scale, integrated studies of biodiversity: the experience of the Program for Biodiversity Research in Brazilian Amazonia. Natureza e Conservação, 8(1): 3-10. D0l

Cuezzo, F. \& Guerrero, R.J. 2011. The Ant Genus Dorymyrmex Mayr (Hymenoptera: Formicidae: Dolichoderinae) in Colombia. Psyche, 2012 (ID article 516058): 1-24. DOI

Dejean, A.; Céréghino, R.; Leponce, M.; Rossi, V.; Roux, 0.; Compin, A.; Delabie, J.H.C. \& Corbara, B. 2015. The fire ant Solenopsis saevissima and habitat disturbance alter ant communities. Biological Conservation, 187: 145-153. D01

Fernandes, I.0.; Oliveira, M.L. \& Delabie, J.H.C. 2014. Description of two new species in the Neotropical Pachycondyla foetida complex (Hymenoptera: Formicidae: Ponerinae) and taxonomic notes on the genus. Myrmecological News, 19: 133-163.

Fernández, F. 2003. Myrmicine ants of the genera Ochetomyrmex and Tranopelta (Hymenoptera: Formicidae). Sociobiology, 41: 633-661.

Fernández, F. \& Sendoya, S. 2004. List of Neotropical ants (Hymenoptera: Formicidae). Biota Colombiana, 5(1): 3-93.

Hölldobler, B. 1979. Territoriality in Ants. Proceedings of the American Philosophical Society, 123(4): 211-218. Available at: www.jstor.org/ stable/986580.

IBGE - Instituto Brasileiro de Geografia e Estatística. 2017. Área dos municípios. Available at:www.ibge.gov.br/home/geociencias/areaterritorial/principal. shtm. Access in: 19/02/2018.

INPE - Instituto Nacional de Pesquisas Espaciais. 2015. Available at: www. inpe.br. Access in: 19/02/2018.

Janicki, J.; Narula, N.; Ziegler, M.; Guénard, B.\& Economo, E.P. 2016. Visualizing and interacting with large-volume biodiversity data using client-server web-mapping applications: The design and implementation of antmaps. org. Ecological Informatics, 32: 185-193. Available at: www.antmaps.org. Access in: 19/02/2018.

Johnson, C. 1989. Taxonomy and diagnosis of Conomyrma insana (Buckley) and C. flava (McCook) (Hymenoptera: Formicidae). Insecta Mundi, 3: 179-194.

Longino, J.T. 2003. The Crematogaster (Hymenoptera, Formicidae, Myrmicinae) of Costa Rica. Zootaxa, 151: 1-150.

Longino, J.T. 2009. Additions to the taxonomy of new world Pheidole (Hymenoptera: Formicidae). Zootaxa, 2181: 1-90.

Mackay, W.P. \& Mackay, E.E. 2010. The systematics and biology of the New World ants of the genus Pachycondyla (Hymenoptera: Formicidae). Lewiston, Edwin Mellen Press. 642p.

Malanson, G.P.; Resler, L.M. \& Tomback, D.F. 2017. Ecotone response to climatic variability depends on stress gradient interactions. Climate Change Responses, 4(1): 2-8.
Mateus, L.; Ortega, J.; Mendes, A. \& Penha, J. 2016. Nonlinear effect of density on trophic niche width and between-Individual Variation in diet in a Neotropical Cichlid. Austral Ecology, 41(5): 492-500.

Oliveira, M.L.; Mariano, C.S.F.; Costa, M.A.; Delabie, J.H.C. \& Lacau, S. 2015. Pheidole protaxi sp. nov. (Hymenoptera: Formicidae), new species from tabuleiro forests of the Atlantic Forest biome. Sociobiology, 62(4): 533-537.

Paolucci, L.N.; Maia, M.L.B.; Solar, R.R.; Campos, R.I.; Schoereder, J.H. \& Andersen, A. 2016. Fire in the Amazon: impact of experimental fuel addition on responses of ants and their interactions with myrmecochorous seeds. Oecologia, 182: 335-346. D01

Ribas, C.R.; Campos, R.B.; Schmidt, F.A. \& Solar, R.R. 2012. Ants as indicators in Brazil: a review with suggestions to improve the use of ants in environmental monitoring programs. Psyche, 2012 (article ID 636749): 1-24. DOI

Rocha, W.D.O.; Dorval, A.; Peres Filho, 0.; Vaez, C.D.A. \& Ribeiro, E.S. 2015. Ants (Hymenoptera: Formicidae) as Bioindicators of Environmental Degradation in Poxoréu, Mato Grosso, Brazil. Floresta e Ambiente, 22(1): $88-98$.

Ryder-Wilkie, K.T.; Mertl, A.L. \& Traniello, J.F.A. 2010. Species diversity and distribution patterns of the ants of Amazonian Ecuador. Plos One, 5(10): e13146. DOI

Santos-Silva, L.; Vicente, R.E. \& Feitosa, R.M. 2016. Ant species (Hymenoptera, Formicidae) of forest fragments and urban areas in a Meridional Amazonian landscape. Check List, 12(3): 1-7.

Silva, F.H.O.; Delabie, J.H.C.; Dos Santos, G.B.; Meurer, E. \& Marques, M.I. 2013. Mini-Winkler extractor and pitfall trap as complementary methods to sample Formicidae. Neotropical Entomology, 42(4): 351-58.

Snelling, R.R. 1995. Systematics of Nearctic ants of the genus Dorymyrmex (Hymenoptera: Formicidae). Contributions in Science, Natural History Museum Los Angeles, 454: 1-14.

Spector, S. \& Ayzama, S. 2003. Rapid turnover and edge effects in dung beetle assemblages (Scarabaeidae) at a Bolivian Neotropical Forest-Savanna Ecotone. Biotropica, 35: 394-404.

Suguituru, S.S.; Rodrigues de Souza, D.; Bortoli Munhae, C.; Pacheco, R. \& Morini, M.S.C. 2013. Diversidade e riqueza de formigas (Hymenoptera: Formicidae) em remanescentes de Mata Atlântica na Bacia Hidrográfica do Alto Tietê, SP. Biota Neotropica, 13(2): 141-152.

Ulysséa, M.A.; Cereto, C.E.; Rosumek, F.B.; Silva, R.R. \& Lopes, B.C. 2011. Updated list of ant species (Hymenoptera, Formicidae) recorded in Santa Catarina State, southern Brazil, with a discussion of research advances and priorities. Revista Brasileira de Entomologia, 55(4): 603-611. D01

Vicente, R.E.; Dáttilo, W. \& Izzo, T.J. 2014. Differential recruitment of Camponotus femoratus (Fabricius) ants in response to ant garden herbivory. Neotropical Entomology, 43: 519-525. DOI

Vicente, R.E.; Prado, L.P. \& Izzo, T.J. 2016. Amazon rainforest Ant-Fauna of Parque Estadual do Cristalino: understory and ground-dwelling Ants. Sociobiology, 63(3): 894-908. D01

Wheeler, G.C. \& Wheeler, J. 1988. A checklist of the ants of Wyoming. Insecta Mundi, 2(3-4): 230-239.

Wilson, E.0. 2003. Pheidole in the new world: a dominant, hyperdiverse ant genus. Cambridge, Harvard University Press.

Zhu, X.; HU, Y. \& Gao, B. 2011. Influence of environment of forest-steppe ecotone on soil Arthropods community in northern Hebei, China. Procedia Environmental Sciences, 10: 1862-1867. 